\title{
Erratum to: Links between lipid homeostasis, organelle morphodynamics and protein trafficking in eukaryotic and plant secretory pathways
}

\author{
Su Melser • Diana Molino • Brigitte Batailler • \\ Martine Peypelut - Maryse Laloi • Valérie Wattelet-Boyer • \\ Yannick Bellec $\cdot$ Jean-Denis Faure $\cdot$ Patrick Moreau
}

Published online: 25 February 2011

(C) Springer-Verlag 2011

Erratum to: Plant Cell Rep (2011) 30:177-193

DOI 10.1007/s00299-010-0954-1

In Fig. 4, the yellow and the purple triangles were interchanged in the inner leaflet of the membrane. The correct version of the figure is produced in the following page.

The online version of the original article can be found under doi:10.1007/s00299-010-0954-1.

S. Melser · V. Wattelet-Boyer · P. Moreau ( $\square)$

Laboratoire de Biogenèse Membranaire, UMR 5200 Université

Bordeaux 2-CNRS, Université Bordeaux 2, case 92,

146 rue Léo-Saignat, 33076 Bordeaux, France

e-mail: pmoreau@biomemb.u-bordeaux2.fr

\section{S. Melser}

e-mail: su.melser@inserm.fr

V. Wattelet-Boyer

e-mail: valerie.wattelet@biomemb.u-bordeaux2.fr

D. Molino $\cdot$ Y. Bellec $\cdot$ J.-D. Faure

Laboratoire de Biologie Cellulaire, INRA UR501,

Versailles, France

e-mail: diana.molino@versailles.inra.fr

Y. Bellec

e-mail: bellec@versailles.inra.fr

J.-D. Faure

e-mail: Jean-Denis.Faure@ versailles.inra.fr

B. Batailler · M. Peypelut $\cdot$ P. Moreau

Pôle Imagerie du Végétal du BIC (Bordeaux Imaging Center), INRA IFR103, Villenave d'Ornon, France e-mail: brigitte.batailler@bordeaux.inra.fr

M. Peypelut

e-mail: peypelut@bordeaux.inra.fr

M. Laloi

Physiologie Moléculaire du Transport des Sucres chez les Végétaux, University of Poitiers, FRE3091 Poitiers, France e-mail: maryse.laloi@univ-poitiers.fr 


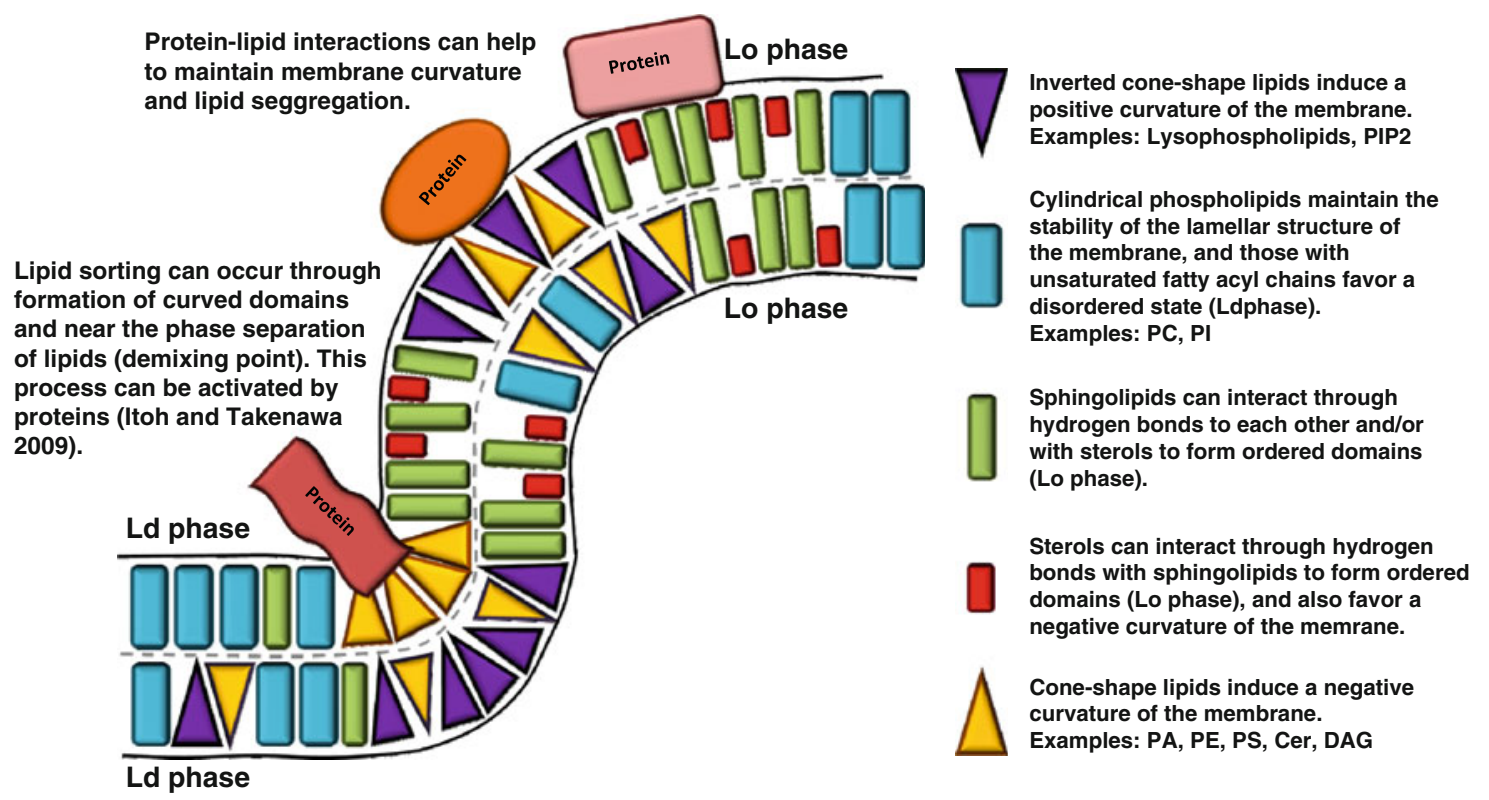

Fig. 4 Structural features of the main lipid families. Lipids which can be segregated in Ld or Lo phase domains as defined in Hammond et al. (2005) are shown. Cone-shape (negative membrane curvature)

and inverted cone-shape lipids (positive membrane curvature) are indicated. Proteins able to interact with specific lipids to form/ maintain specific membrane domains are also illustrated 